Каневская Ольга, кандидат педагогических наук, доцент, доцент кафедры русской филологии и зарубежной литературы Криворожский государственный педагогический университет

\title{
СПЕЦИФИКА СОЗДАНИЯ КОМИЗМА В ИДИОСТИЛЕ Г. ГОРИНА
}

У статті визначено спеиифіку створення комізму в ідіостилі Г. Горіна. Проаналізовано мовні засоби (фонетичні, лексико-фразеологічні) та прийоми (доведення до абсурду, подвійне тлумачення, порівняння, протиставлення) комізму, характерні для творчої манери драматурга. Установлено, щзо в його творах поєднано ліризм $i$ тонкий гумор, психологізм і філософський погляд на світ. Майстерне володіння всіма прийомами та засобами комізму, разом із комізмом ситуаиії та комізмом характеру, створюють особливий ідіостиль Горіна, в якому відбивається авторське світосприйняття.

Ключові слова: комізм, прийом створення комізму, засіб створення комізму, ідіостиль, Г. Горін.

Kanevskaya $O$. Specificity of the creation of a comic in the idiostyle of G. Horin.

The article specifies the specificity of the creation of a comic in the G. Horin's idiostyle. The linguistic means (phonetic, lexico-phraseological) and devices (reduction to absurdity, double 
interpretation, comparison, opposition) of the comic, which characterize the playwright's creative manner, are analyzed. It is established that in his works lyricism and subtle humor, psychology and a philosophical view of the world are combined. The mastery of all devices and means of comism, together with the comism of the situation and the comism of the character, create a special Gorin's idiostyle, which reflects the author's perception of the world.

Key words: comic, device of creation of a comic, means of creation of a comic, idiostyle, G. Gorin.

Исследование идиостилей разных писателей и поэтов давно стало предметом изучения лингвистики: наблюдению подлежит область словесного искусства, где средства языка преобразуются согласно законам искусства. Не подлежит сомнению тот факт, что выбор языковых средств и стилистических приёмов в художественном тексте, обусловленный эмоциональным, интеллектуальным, творческим опытом автора, определяет языковую художественную систему произведения и одновременно вытекает из неё.

Механизмы порождения комического хотя и имеют универсальный характер, но у каждого писателя реализуются по-разному, создавая тем самым неповторимый идиостиль. Собственно, само понятие «комическое» как эстетическая категория рассматривается и искусствоведением, и литературоведением (М. М. Бахтин, Ю. Б. Борев, А. З. Вулис, Б. О. Дземидок, Л. Ф. Ершов, А. Н. Лук, В. Я. Пропп и др.), и лингвистикой (В. Б. Брякин, В. Н. Виноградова, М. А. Генкель, А. Земская, Л. П. Иванова, В. М. Костюков, С. И. Походня, Г. Г. Почепцов и др.). Исследователи решают проблемы природы и сущности комического, его систематизации, исторической изменчивости, жанровых разновидностей, приёмов и средств порождения комизма в художественном тексте.

Нам представляется актуальным, новым и целесообразным изучение идиостиля Григория Горина именно в аспекте анализа приёмов и языковых средств создания комизма, так как творчество этого замечательного русского писателя-сатирика до сих пор остаётся без внимания филологов.

Цель статьи - выявить специфику создания комизма в идиостиле Г. Горина. 
Материалом для исследования послужили его киноповести: «Формула любви», «Тот самый Мюнхгаузен», «Дом, который построил Свифт», а также трагикомедии: «Забыть Герострата!», «...Чума на оба ваши дома!».

Проведённый нами анализ текстов пьес Г. Горина показал, что драматург, чутко относящийся к слову и сознающий его неисчерпаемые возможности, умело использовал в своих произведениях весь арсенал комизма, творчески перерабатывая традиционные приёмы и средства и существенно обновляя их.

Так, для горинских произведений характерна комическая экспрессия, где комизм характеров напрямую связан с комизмом ситуаций. Языковые приёмы комического основываются на «намеренном нарушении принятого способа выражения» и состоят в «создании противоречия между общепринятой системой выражения $u$ данной» [1, с. 218]. Г. Горин достаточно часто использует в текстах два ряда характерологических средств: штампы с «высоким экспрессивнылм ореолом» [2, с. 15] и разговорную лексику, подчёркивающую нелепость ситуации, персонажа и т.п., т.к. соединение стилистически контрастных слов (например: высокое + просторечное) порождает общий комический эффект:

- Калиостро! - равнодушно сказал доктор. - Известньй чародей и магистр тайных сил. Говорят, в Петербурге наделал много иуму... Камни драгоченные растил, будущиость предсказывал... А вот ещё, говорят, фрейлине Головкиной из медальона вывел образ её покойного мужа, да так, что она его осязала и теперь вроде как на сносях... // - Материализация! воскликнул Федешев и, вскочив, нервно стал расхаживать по кабинету. - Это называется “материализация чувственных идей”. Я читал об этих таинствах... О Боже!! [3, с. 284]. Ср.: книжная (будущуность, материализация, чувственные идеи, таинства) + разговорная (на сносях, наделал много иуму) лексика.

- ..Река жнизни утекает в Вечность. При чём тут «окуньки»? [3, с. 278] (река жизни, Вечность - поэтическое; окуньки - разговорное). 
- Ипохондрией мается, - пояснила тётушка. // - Вижу, - сказал доктор и снова налил рюмочку. - Ипохондрия есть жестокое любострастие, которое содержит дух в непрерьвном печальном положении... [3, с. 283] (ипохондрия, любострастие - книжное, устаревшее; мается, рюмочка разговорное).

Для создания иронии автор умело использует приём двойного истолкования: - Не забудьте про волнения в Ковентри, - подсказал епископ. А также о том трудном положсении, в котором находится принцесса Маргарет. // - Принцеесса в положении? - неожиданно заинтересовался губернатор. // - В переносном смысле, - пояснил судья. // - Да? - лицуо у губернатора отразило работу мысли. - И от кого? // - Трудно сказать, наконец выдавил из себя судья, - но переписывалась она с Вольтером... // Получается, у нас нет своих философов?! // Наступила пауза. Вопрос всех поставил в тупик [3, с. 349]; - Погодь! Погодь, любезнейший, - заволновались лакеи. - Откуда тузы? Тузы ушли! // - Тузы не уходят, - насмешливо произнёс Маргадон. - Тузы удаляются [3, с. 275].

На буквализации слов (буквальном понимании их значений) строится приём обратного сравнения, характерный для идиостиля Г. Горина, например: Доктор (отложив меч). Я не люблю глупьх иуток, мистер Глюм. Я приехал драться с великаном. Bbl же человек среднего роста. Футов шесть, не больше... // Глюм. Пять футов восемь дюймов. И всё-таки, сэр, я действительно великан. Самый настоящийц! Я понимаю, в это трудно поверить, но это так. Я опустился [3, с. 333]; - Передайте декану, что его книга имеет у меня оглушительный успех! - Размахнулся и со всей силь запустил книгой в стекло. За окном зааплодировали [3, с. 357].

Комизм строится и на разнообразных повторах, прежде всего лексических: - Ах, тётушка. Для того ли я оставил свет, убежал из столиць, чтоб погрязнуть в болоте житейском?.. Ну женюсь, и что будет? Стану цельми днями ходить в халате да играть в карты с гостями... - Федямева даже передёрнуло. - А жена моя, особа, которая должна служить идеалом 
любви, будет, гремя ключами, бегать в амбар. А то и.. совсем страмно... закажет при мне лапшу и начнёт её кушать? // - Зачем же она непременно лапшу станет кушать, Алексей! - чуть не подавилась тётушка. - Да хоть бы и лапшу... Ну, что тут плохого? [3, с. 279]; - При жсивой жсене вы не можете жениться вторично. // - Bы говорите «при ж⿻ивой»? - задумался Мюнхгаузен. // - При жнивой, - подтвердил пастор. // - Bы предлагаете ёе убить? // - Упаси Бог! - испугался пастор... [3, с. 217].

Интересно использование приёма сравнения по неявному, случайному или несущественному признаку: - Ну откуда в Италии мята? - возразил доктор. - Видел я их Италию на карте, сапог сапогом, и всё! [3, с. 308]; Напротив - слуга Маргадон, устальй мужчина неопределённого возраста, похожий на кота и мышь одновременно [3, с. 272]; - Именно на уровне груди!- воскликнул гериог, делая необходимые замеры портновским сантиметром. - Я не разрешу опускать талию на бёдра. В конце концов, мы - центр Европы, и не позволю всяким там испанцуам диктовать нам условия. Хотите отрезной рукав, пожалуйста! Хотите плиссированную юбку с выточками, принимаю и это! Но опускать талию не дам! [3, с. 224].

Нередко Г. Горин обыгрывает перифразы: - Bom черти!.. До слёз, буквально до слёз... Бестии эдакие... Молодцы!.. Повесить бы, конечно, чтоб другим неповадно... Но в такой день - прощуаю!.. [3, с. 186]; Ну, барин, тут тогда самому не справиться. Помощник нужен, хомо сапиенс! [3, с. 291].

Г. Горин активно использует явление антонимии, которое играет ведущую роль в создании антитезы, что является подкреплением такого действенного приёма комического эффекта, как противопоставление: Герострат. Люди не прощцют тому, кто умнее их. // Клеон. Люди не прощают тому, кто считает их дураками [3, с. 98]; - Погрузить в себя, сэр! посоветовал Жакоб. - В тайники своей души... // - Там холодно и страшно, отмахнулся Маргадон. - Лучше уж заботиться о теле [3, с. 295]; - Ему плохо? - спросила Мария... // - Ему хорошо, - ответил доктор. Живым всё 
хорошо... Пуля-то, слава Богу, только кожу задела. Рука у вас, граф, выходит, умней головы... Та говорит: «Стреляй в меня», а эта не хочет [3, с. 308].

В следующем контексте:-Он слеп? // - Напротив, сэр! - зашептал один из горожан. - Декан прекрасно видит... Но часто видит всё наоборот. Поэтому он и прикрыл глаза, чтоб взглядом никого не обеспокоить [3, с. 313], - антонимы создают ложное противопоставление, наблюдается наращение смысла, иронический подтекст: видит всё наоборот, поэтому он слеп (прикрыл глаза).

В примере: - Болтает? // - Молчит. // - Умный мальчик. Далеко nойдёm [3, с. 253], - антитеза построена на антонимической паре: болтает молчит, алогичность вывода создаёт комический эффект.

На антитезе строится парадокс: - Так ж⿻ив он? - совсем растерялся доктор. // - Кто? - горожане тупо смотрят на него. // - Декан! // - Как жсив, когда вам говорят, что умер, - заговорили горожане наперебой. - Уж и в газетах было извещение. И колокол собора затрезвонил... Да вот он сам идёт ... // - Kто? // - Свифт. Хоть у него спросите... [3, с. 313].

Необходимо подчеркнуть, что горинский парадокс чаще всего строится на абсурде и гротеске: Затем строгий голос спросил: «А почему этот человек до сих пор жив?» Кто-то подобострастно ответил: «Он репетирует свою смерть, ваше превосходительство!» [3, с. 319]; - Эпидемия безумия, - быстро сформулировал учёный. - Когда сходит с ума простой человек - это незаметно, но когда взрывается такой мощцный интеллект, как Свифт, мысли и образы летят во все стороны [3, с. 351].

Умело драматург пользуется гиперболизацией, доводя ситуацию (эпизод) до абсурда: - Жалкие комедианты! Я бы мог вас испепелить, превратить в прах!.. Вы сего недостойны! Я поступлю с вами прощуе: сдам в участок. Вас станут судить за кражу серебряных ложек и неоплаченные счета $в$ трактире! A потом публично выпорют, как бродяг, и отправят в Сибирь убирать снег! // - Весь? - ужаснулся Маргадон. // - Весь, - ответил Калиостро [3, с. 299]; - Сколько вам лет, сэр? // - Тридизать. Какое это имеет 
значение? // - Предьдущеему доктору тоже было тридцать, - вздохнул Патрик. - Ушёл от нас - семидесяти. А проработал всего неделю... [3, с. 317]; - Видите - растёт дуб? Вон тот, огромный... Прекрасный собеседник для вас: ему тоже лет пятьсот. // - Уже пятьсот? Боже! Я ведь помню его ещё жнёлудем [3, с. 316].

Григорий Горин с целью создания комизма использует разнообразные фонетизмы: - Она! - авторитетно сказал дед. - А может и не она... Та была брунетка, а эта вся белая... [3, с. 282]; - Жуткие нравы! - произнёс Маргадон. - Уж где только не дуэлировали... и во Франции... и в Голландии... Быстро и чётко, как принято у цчивилизованных людей: рраз - и наповал! [3, с. 305]. Эффективным средством, характеризующим речь персонажей, является нарушение фонетических и грамматических норм:- $\boldsymbol{Я}$ не есть это мочь! - в отчаянии закричала Лоренц̧а. - Моя голова... ничт... не мочь это запоминайт... [3, с. 272].

Характерологическим средством становятся и варваризмы: Натюрлих! - ответил Маргадон почему-то по-немецяки. - Только плечи иире... И бёдра... [3, с. 294]; - О мама миа, коза дичи! Нон вольво! Э пойзо! Дьяболо! - разгневанная Лорени̧а в ярости расхаживала по гостиничному номеру [3, с. 272]; - Силь ву пле, дорогие, силь ву пле, - бормотала Федосья Ивановна. - Же ву тру... А, чёрт, все слова-то со страху повыскакивали [3, с. 290]; - Ма тант! - строго сказал Федяшев, сбиваясь частично на французский язык и тем самым пытаясь сделать непонятной ссору для наблюдательных простолюдинов. - Не будем устраивать эль скандаль при посторонних... [3, с. 281-282]. Как показывает анализируемый материал, особенностью горинского стиля являются стилистические контрасты в микротекстах, обусловленные потребностью выражения комизма.

Характерно для идиостиля Горина использование в качестве средства комизма фразеологизмов, крылатых слов, пословиц, которые автор вводит в текст разными способами: без всяких изменений; включает в текст, восстанавливая образность фразеологической единицы, что приводит к полной 
или частичной её «деформации»; ставит фразеологизм в не свойственный ему стилистический контекст. Например: - Тогда не валяй дурака, стань таким, как все! [3, с. 336] (включение без изменений); А тут ещеё я начал расти не по дням, а по часам, поднимаясь фут за футом над уровнем сограждан. Скоро я уже наблюдал свою землю с высоты птичьего полёта... [3, с. 335] (буквализация фразеологизма); Нет зрелищуа азартнее на свете, // Чем зрелище борьбы Монтекки с Капулетти! [3, с. 144] (изменение лексического состава);Пожалуйста! - Маргадон сделал лёгкий поклон и продекламировал: «Учиться- всегда сгодиться! Трудиться должна девица. Не плюй в колодец-пригодится»... [3, с. 273] (нагромождение фразеологизмов в одном контексте); Когда всё это случилось, епископ сначала рэнал, как мерин, а потом заплакал крокодиловыми слезами и сказал, что бессилен нам помочь [3, с. 195] (использование различных по стилистической окраске фразеологизмов, антонимичных по своему содержанию). Используемые автором приёмы не только разрушают автоматизм восприятия фразеологизма, повышают его экспрессивность, изменяют сферу её приложения и стилистической или семантической сочетаемости, но и являются эффективными средствами создания комического эффекта.

В целом, Г. Горин обнаруживает пристрастие к афористическому языку, умело вставляя в текст разнообразные идиомы и крылатые выражения. Многие афоризмы создаёт сам: - ... Год рождения... Год смерти... Всё расписано на небесах. Что же остаётся человеку? Подробности! Придумай подробности сочинишь судьбу!.. [3, с. 366]; Смерть боится казаться смешной! Это её уязвимое место... Того, кто над ней смеётся, она обходит стороной... [3, с. 366]; Сэр, у великанов, $к$ сожалению, всё чрезмерно - зрение, слух, совесть [3, с. 335]; Идеал нельзя отрывать от почвы! [3, с. 295]; Нелюбовь к ближнему - это то, что объединяет сердца [3, с. 158].

Таким образом, в пьесах Г. Горина соединены лиризм и тонкий юмор, психологизм и философский взгляд на мир. 
Исследование логической структуры отобранных нами речевых фактов показало, что чаще других приёмов, способствующих созданию комического эффекта, писатель использовал противопоставление, логическую несовместимость, повтор, доведение до абсурда, иронию, парадокс и др.

На создание комического эффекта в произведениях влияют фонетические, словообразовательные и морфологические средства языка. Г. Горин не злоупотребляет ими, они немногочисленны в его произведениях, но важны в создании комизма, помогают осуществить сатирический или юмористический замысел автора.

Особенностью идиостиля Г. Горина является использование набора лексико-стилистических средств, создающих комический эффект, среди которых наиболее активны нарочитое использование разговорно-просторечной лексики, употребление варваризмов, столкновение стилистически несовместимых единиц, а также игра слов, которая построена на использовании в одном контексте синонимов (в том числе и контекстуальных), на явлении паронимии, буквализации значения слова или его уточнении.

Для горинских произведений характерны афористичность языка, умелое использование фразеологизмов. Комизм достигается путём «деформации» фразеологических единиц (введением во фразеологизм уточняющих слов и выражений, игрой на внутренней форме фразеологизма, заменой одного из членов фразеологического сочетания; смещением двух фразеологизмов и др.).

Мастерское владение всеми приёмами и средствами комизма, наряду с комизмом ситуации и комизмом характеров, создают особый горинский идиостиль, в котором отражается авторское мировосприятие.

Перспективным направлением исследования, по нашему мнению, является комплексное изучение поэтики произведений Г. Горина, представляющих его художественную картину мира. 


\section{Литература}

1. Земская Е. А.Речевые приёмы комического в советской литературе / Е. А. Земская // Исследования по языку советских писателей. - Москва : Изд-во AH CCCP, 1959. - C. 215-278.

2. Борев Ю. Б. О комическом / Ю. Б. Борев. - Москва : Искусство, 1957. $232 \mathrm{c}$.

3. Горин Г. И. Дом, который построил Свифт / Г. И. Горин. - Киев : Издво «Довира», 1995. - 398 с. 